\section{Patents and Information in Genes: Australia, Policy and the Distinction between DNA and CDNA}

\section{Introduction}

As in the United States, a prohibition on patenting isolated genetic sequences has now been recognized in Australia. On 7 October 2015, the High Court of Australia in D'Arcy v Myriad Genetics Inc., ruled unanimously that an isolated nucleic acid coding for mutant or polymorphic forms of the $B R C A 1$ polypeptide is not a patentable invention [1]. As a consequence, it invalidated Myriad's BRCA1 patent which claimed an isolated mutated $B R C A 1$ gene sequence.

The Australian court's decision largely follows that of the Supreme Court of the United States in Association for Molecular Pathology v. Myriad Genetics, Inc., which found Myriad's US patents invalid [2]. In that case, the Supreme Court held that a naturally occurring DNA segment is a product of nature and not patent eligible merely because it has been isolated, but that synthetic complementary DNA (cDNA) sequences produced in laboratory but determined by the natural order of gene exons are patent eligible because they are not naturally occurring

Like the Supreme Court's decision that preceded it, the Australian court regarded DNA as a special class of subject matter by reason of the information it encodes, and as such, treated it differently to other chemical substances when considering its patentability. However, the Australian court's decision differed in one important respect: it also regarded cDNA as unpatentable for the reason that, even though synthesized cDNA is not a naturally occurring phenomenon, it replicates a naturally occurring sequence of exons.

The United States and Australian decisions now place those countries' laws at odds with the laws of other jurisdictions, such as Europe and China, where isolated nucleic acid sequences are patentable.

\section{Claiming a DNA Sequence}

By dint of extensive, time-consuming and costly research, Myriad discovered the precise location and sequence of two human genes that have a propensity to mutate [3]. When mutated, these genes can substantially increase the risk of breast and ovarian cancer. Myriad obtained a number of patents, based on its discovery, over the relevant isolated nucleic acid coding in the United States, Australia and in other countries.

Myriad's Australian Patent No 686004 related to the use of mutations or polymorphisms in the BRCA1 gene to diagnose a subject's susceptibility to breast and ovarian cancer. The patent included claims to products such as isolated nucleic acids, probes and vectors, as well as methods of diagnosis using those products.

\section{Journal of \\ Clinical Trials \& Patenting}

\author{
Ben McEniery \\ Senior Lecturer, Faculty of Law, Queensland University of \\ Technology, Australia \\ *Address for Correspondence: \\ Ben McEniery, BA, LLB (Hons), LLM, PhD, Senior Lecturer, Faculty of \\ Law, Queensland University of Technology, Barrister-at-Law, Brisbane, \\ Australia, E-mail: b.mceniery@qut.edu.au \\ Submission: 31 October, 2015 \\ Accepted: 29 February, 2016 \\ Published: 4 March, 2016 \\ Copyright: () 2016 McEniery B. This is an open access article distributed \\ under the Creative Commons Attribution License, which permits \\ unrestricted use, distribution, and reproduction in any medium, provided \\ the original work is properly cited.
}

The utility of the patent lay in the fact that the invention it disclosed could be used to identify mutations or polymorphisms in a test subject's $B R C A 1$ gene and thus make a diagnosis as to the subject's susceptibility to breast and ovarian cancer.

Claim 1 of the Myriad patent in question was directed to an "isolated nucleic acid coding for a mutant or polymorphic BRCA1 polypeptide". It encompassed a nucleic acid sequence or protein removed from its naturally occurring cellular environment. It is important to note that the disallowed claims were product claims (that is claims to a chemically and physically isolated nucleic acid), and not claims to processes or methods by which the genetic sequences could be isolated.

\section{The High Court's Decision}

The challenge to Myriad Genetics' Australian patent was brought by Ms. Yvonne D'Arcy, an Australian cancer survivor, who took the matter from the Australian Patent Office all the way to her nation's highest court.

The High Court of Australia unanimously held that Myriad's claims to isolated nucleic acids which encode a naturally occurring human protein were invalid for lack of subject matter eligibility [1]. In doing so, the High Court overturned a unanimous decision of a five-judge bench of the Full Court of the Federal Court of Australia below that had reached the opposite conclusion, and had roundly criticized the United States Supreme Court in doing so [4].

Although the High Court's ruling was unanimous, the judges' reasoning was delivered in three separate judgments. The majority of French CJ, Kiefel, Bell and Keane JJ held that the claims at issue did not lie within the established boundaries of patentable subject matter and that it was not appropriate for the judiciary to extend those boundaries; but rather the decision as to whether to do so was one to be taken by the legislature.

An issue that is considered significant at law when the patentability of claimed inventions based on discoveries is considered is whether a naturally-occurring substance is altered (such that what is claimed 
to be a patentable invention is functionally distinct from that which occurs in nature). Critically, the court found that the information stored in genetic sequences is not modified simply because the chemical molecules that compose the subject matter of the claim have been isolated. The judges who formed the court's majority rejected the argument that had been accepted by the court below that isolated nucleic acids are simply chemical compounds, and that the required change could be a physical one, such as the breaking of covalent bonds upon isolation [4]. The court opined that such an argument elevates form over substance and found that the information encoded in the relevant sequences is not something that is made or altered as a consequence of human intervention. The court also noted, as the Supreme Court before it had, that none of Myriad's claims were expressed in terms of chemical composition, but rather focused on the genetic information encoded in the genes.

The court's majority took the view that the mere fact that an isolated nucleic acid is something that is a result of human intervention is not enough to bring it within the scope of patentable subject matter. In this regard, the court held that.

"Although it may be said in a formal sense that the invention as claimed, referring to isolated nucleic acids, embodies a product created by human action, which is not sufficient to support its characterization as [patent eligible subject matter]. The substance of the invention as claimed and the considerations flowing from its substance militate against that characterization. To include it within the scope of [patent eligible subject matter] involves an extension of that concept, which is not appropriate for judicial determination"[1].

The court disagreed with the US Supreme Court's corresponding 2013 decision in relation to one point. The court drew, for the purposes of patentability, no distinction between DNA and cDNA, which contrasts with the position taken by the US Supreme Court. cDNA generally arises from reverse transcription of mRNA, which is not a naturally occurring phenomenon and is a process that requires human intervention. The Supreme Court regarded cDNA as patentable on the basis that it was artificially created, and therefore not a product of nature [2]. The High Court's majority found cDNA unpatentable because of the information it carries. The majority said

"Used in that sense, the information stored in the sequence of nucleotides coding for the mutated or polymorphic BRCA1 polypeptide is the same information as that contained in the DNA of the person from which the nucleic acid was isolated. It is the existence of that information which is an essential element of the invention as claimed. The product is the medium in which that information resides. That characteristic also attaches to cDNA, covered by the claims which is synthesized but replicates a naturally occurring sequence of exons" [1].

In something of an unusual course of action, the majority set out a list of factors to be considered in establishing whether a new class of claimed invention could or should be patentable. That list included:

- Whether recognizing patentability in a new class of claim would be consistent with the purposes of the Act;

- Whether the invention as claimed could give rise to a large new field of monopoly protection with potentially negative effects on innovation;
- Whether the invention as claimed could have a chilling effect on activities beyond those formally the subject of the exclusive rights granted to the patentee (which might include follow-on inventions that require use of the patented product or process);

- Whether to accord patentability would involve a court assessing important and conflicting public and private interests and purposes; and

- Whether to accord patentability to the invention as claimed would enhance or detract from the coherence of the law relating to inherent patentability.

The High Court's decision brings finality to the litigation of Myriad's patents in Australia, as that court is that country's highest court of appeal.

Unlike the United States litigation, which considered Myriad's patents on both the BRCA1 and BRCA2 genes, the Australian litigation only considered Myriad's claim to the BRCA1 gene. The reason behind this strategic choice in the conduct of the litigation is not made clear from a reading of the court's judgment. One can perhaps speculate that the reason was that the parties agreed to simplify the proceeding (at least initially) by confining the issues in dispute on the understanding that if the central claim of one of Myriad's patents were to fall, then all of its BRAC1 and BRCA2 gene patents should fall.

\section{The United States Litigation}

The United States challenge to Myriad's patents case was originally filed in the Court of Appeals for the Southern District Court of New York, which is where the argument that genetic materials should be considered different from ordinary compositions of matter by virtue of their information-carrying characteristics first arose. In that first instance decision, Judge Sweet of the Southern District Court of New York ruled the patents invalid on the basis that Myriad had sought to patent a "product of nature" for the reason that the claimed isolated DNA was not "markedly different" from native DNA. Judge Sweet also ruled that Myriad's arguments in favor of patentability ignored the informational characteristics of DNA that enables it to direct the synthesis of other molecules in the body. Finally, Judge Sweet ruled Myriad's claims to methods to diagnose a susceptibility to breast or ovarian cancer by analyzing and comparing patient samples with a control sample invalid.

Myriad then appealed to the United States Court of Appeals for the Federal Circuit, which overturned Judge Sweet's decision in respect of the product claims to isolated gene sequences. The Federal Circuit in holding the patent valid focused on the chemical, rather than the information-carrying characteristics of the gene sequences. It held that they isolated genes in question were not the same as those found in nature in the human genome, and required considerable expertise and skill to isolate.

The plaintiffs appealed to the Supreme Court of the United States, which granted certiorari, and remanded the proceeding to the Federal Circuit for reconsideration in light of the then recently handed down decision in Mayo Collaborative Services v. Prometheus Laboratories, Inc., [5]. The Federal Circuit reaffirmed its earlier decision, and on 
September 25, 2012, the American Civil Liberties Union and the Public Patent Foundation filed a petition for certiorari with the Supreme Court seeking to overturn the Federal Circuit's second decision.

On June 13, 2013, the Supreme Court unanimously declared Myriad's claims to isolated DNA invalid for the reason that a naturally occurring DNA segment is a product of nature and not patent eligible merely because it has been isolated. The court, however, found that synthetic complementary DNA is patent eligible because it is not naturally occurring.

\section{Myriad in Light of Recent Supreme Court Cases of Patent Eligibility}

The Australian and United States Myriad gene patent cases follow a spate of patent eligibility cases decided by the United States Supreme Court in recent times that read down or limit the scope of patent eligible subject matter. After a generation-long hiatus that began with it handing down its decision in Diamond v. Diehr, in 1981 [6], the Supreme Court has considered three "bleeding-edge" patentable subject matter cases in the last five years.

In its 2010 decision in Bilski v. Kappos, the Supreme Court determined that a method of hedging risk in electricity markets (the idea being to minimize the input costs of an electricity provider that must sell to consumers at a fixed rate despite purchasing at a variable rate) was not patentable [7]. In what was a controversial decision, the court reasoned that a method of hedging risk was nothing more than an abstract idea rather than a patent-eligible invention.

Similarly, in Alice Corp. Pty. Ltd. v. CLS Bank Int'l, Alice sought patents in respect of a computerized trading platform that eliminates "counterparty" or "settlement" risk, being the risk that only one party to a financial transaction performs its obligation to pay, leaving the other party without its principal or the benefit of the counterparty's performance [8]. As in Bilski v. Kappos, the court in Alice Corp. Pty. Ltd. v. CLS Bank Int'l invalidated Alice's patents on the ground that their claims also were drawn to a patent-ineligible abstract idea.

Finally, in Mayo Collaborative Services v. Prometheus Laboratories, Inc., the Supreme Court unanimously ruled that two patents that each disclosed of a method of optimizing a form of providing medical treatment to humans were not patent eligible because they impermissibly were directed to a "law of nature" [5]. The methods involved identifying the optimal dose of a thiopurine drug to give to treat autoimmune conditions, so as to maximize the treatment's effectiveness and minimize its side effects. The diagnostic element of the method involved an iterative testing mechanism in which a drug is injected into a patient and the patient's metabolic response is measured, with subsequent doses being re-calibrated according to the measured metabolic response. The patentee, Prometheus Laboratories sued Mayo alleging patent infringement. Mayo counterclaimed seeking revocation of the patent on the ground that the patent was invalid. In an unanimous decision, the Supreme Court overturned the finding of the Court of Appeals for the Federal Circuit below and ruled that the claimed methods add nothing to the laws of nature that is not already present when their steps are considered separately.

What these cases demonstrate is a concerted effort by the US
Supreme Court to narrow the recognized scope of patentable subject matter by expanding the purview of the "abstract ideas" and "product of nature" categories of excluded subject matter. The US Supreme Court's decision in the Myriad litigation is consistent with the new perspectives on patenting and the legal approach established in these cases, but is not necessarily consistent with using the patent incentive to encourage the development of new and innovative methods in the healthcare sector.

\section{Conclusion}

The outcomes of the Myriad litigation in both Australia and the United States make clear that isolated gene sequences are not patentable. It marks the end of a period in which judges regard genes and genetic sequences as patentable simply because they possess a powerful new utility.

From a practical point of view, in terms of isolated nucleic acid molecules, the decisions are likely to have little impact since it is now recognized that the many gene sequencing and isolation techniques are well understood in the scientific community.

The Australian High Court's decision demonstrates that patents will not be awarded as an incentive to encourage extensive, timeconsuming and costly research to reveal hither to undiscovered scientific secrets. Rather, it sets a high bar on the creativity required to adapt a naturally-occurring phenomenon to produce a product of commercial utility (which is arguably a higher bar than that set by the US Supreme Court given that courts permissive views on the patentability of cDNA).

The courts' decisions depart from decades of reductionism that equated genes and genetic sequences to chemical molecules like any other [9], however this was never an obvious choice. The former law regarded a gene as "a chemical compound, albeit a complex one" [10]. The decision to recognize that the information-coding aspects of genes and genetic sequences and their ability to communicate hereditable traits sets them aside from ordinary chemical substances arguably flies in the face of common law orthodoxy on patentable subject matter eligibility that looks to practical utility as the hallmark of patent eligibility [11].

The decisions also represent another example of courts adopting a "gate keeping" role of barring patents of a particular subject matter, rather than employing the tools of novelty and non-obviousness [12]. Genes are now, to use an expression used by Justice Douglas of the United States Supreme Court, "part of the storehouse of knowledge of all men" [13]. They will invariably lead to an opening of the diagnosis market to competition in the absence of exclusive monopoly rights: as soon as Myriad's US patents were invalidated, no fewer than six laboratories put their tests on the market. However, like its counterpart in the United States, the Australian court's decision does not leave researchers or investors without incentives to conduct medical research. The courts' decisions do leave open the possibility for patents over artificially created DNA or cDNA that does not completely or substantially replicate the informational content of naturally occurring DNA. Innovation in diagnostic test and treatment also remain open to patenting where the methods in question involve more than an obvious application of knowledge gleaned from a discovery of a natural phenomenon. 
An interesting aspect of these cases is that, in the absence of definitive court judgments that resolve the question, it is seemingly impossible to come to a definitive conclusion as to the validity of Myriad's patents using existing legal principles and frameworks. The language of patent law arguably does not answer the question of whether isolated genes or gene sequences are unpatentable by virtue of the information they contain or are patentable because they are chemically and physically different to substances that are found in the human body. Those decisions, however, reverse decades of what were accepted expectations and practices in relation to the patentability of genes. Although the decisions in both countries now provide clear guidance on what the law is, it must be accepted that, given the absence of clear and binding antecedent precedent, the decisions are policy decisions; that is, they rest upon the vales and aspirations of the judges who constituted the courts. As is clear from the fact the Full Federal Court and the Federal Circuit below in Australia and the United States respectively reached the opposite conclusion, reasonable minds may differ particularly when the aims and credibility of the patent system are at stake.

That the decisions in both jurisdictions are another stepping point on the evolution of the scope of patent-eligible subject matter is possibly best understood in the context of the comment of Justice Hayne in the Australian High Court's decision in Apotex Pty Ltd $v$ Sanofi-Aventis Australia Pty Ltd, where his honour noted that, "the conception of what is a proper subject for the grant of a patent is not to be understood except as an historical growth. In the development of that conception, "history is likely to predominate over logic or pure reason"' [14].

The decisions represent a first step in providing the life sciences with a definitive and modern interpretation of the product of nature doctrine and its scope and some analysis of how correlations in the life sciences are defined as natural phenomena or laws of nature. What remains to be seen is what implications the non-eligibility of genes for patenting has for the patenting of other genetic testing methods and the patent-eligibility of other biomolecules.

\section{References}

1. D’Arcy v Myriad Genetics Inc [2015] HCA 35.

2. Association for Molecular Pathology v. Myriad Genetics, Inc. (2013) 569 U.S. 133 S.Ct. 2107.

3. Williams-Jones B (2002) History of a gene patent: tracing the development and application of commercial BRCA testing. Health Law J 10: 123-146.

4. D'Arcy v Myriad Genetics Inc (2014) FCAFC 115.

5. Mayo Collaborative Servs. v. Prometheus Labs., Inc. (2012) 566 U.S. 132 S.Ct. 1289.

6. Diamond v. Diehr (1981) 450 U.S. 175.

7. Bilski v. Kappos (2010) 561 U.S. 593.

8. Alice Corp. v. CLS Bank Int'l (2014) 573 U.S.__, 134 S.Ct. 2347.

9. Beauchamp C (2013) Patenting nature: a problem of history. Stanf Technol Law Rev 16: 257-312.

10. Amgen Inc., v. Chugai Pharmaceutical Co., Ltd., 927 F.2d 1200.

11. McEniery B (2011) Physicality in the information age: a normative perspective on the patent eligibility of non-physical methods. Chi-Kent Law Rev 10: 106167.

12. Kane EM (2011) Patenting genes and genetic Methods: what's at stake? J Bus Technol Law 6: 1-34.

13. Funk Brothers Seed Co. v. Kalo Inoculant Co., (1948) 333 U.S. 127.

14. Apotex Pty Ltd v Sanofi-Aventis Australia Pty Ltd (2013) HCA 50. 